\title{
Titanium Dioxide Nanoparticles Induced Proinflammation of Primary Cultured Cardiac Myocytes of Rat
}

\author{
Wei Song, ${ }^{1,2}$ Jiangxue Wang, ${ }^{1,2}$ Meili Liu, ${ }^{1}$ Ping Li, ${ }^{1}$ Gang Zhou, ${ }^{1} \mathrm{Zhou} \mathrm{Li}^{1}{ }^{1}$ and Yubo Fan ${ }^{1,2}$ \\ ${ }^{1}$ Key Laboratory for Biomechanics and Mechanobiology of Ministry of Education, School of Biological Science and Medical Engineering, \\ Beihang University, Beijing 100191, China \\ ${ }^{2}$ Research Institute of Beihang University in Shenzhen, Shenzhen 518057, China
}

Correspondence should be addressed to Yubo Fan; yubofan@buaa.edu.cn

Received 14 June 2013; Accepted 26 July 2013

Academic Editor: Xiaoming Li

Copyright (C) 2013 Wei Song et al. This is an open access article distributed under the Creative Commons Attribution License, which permits unrestricted use, distribution, and reproduction in any medium, provided the original work is properly cited.

\begin{abstract}
Titanium dioxide $\left(\mathrm{TiO}_{2}\right)$ nanoparticles are widely used in electronics, biology, and medicine owing to their special properties. However, during $\mathrm{TiO}_{2}$ nanoparticles exposure, nanoparticles may enter the blood circulation and translocate to the heart, and they may result in negative effects on the cardiovascular system. In this study, we demonstrated that the anatase and rutile $\mathrm{TiO}_{2}$ nanoparticles had potential toxicological effects on primary cultured cardiac myocytes of rat. After incubating with the anatase and rutile $\mathrm{TiO}_{2}$ nanoparticles, the primary cultured cardiac myocytes had become elongated and appeared to detach from the surface of cell plate. After exposure to 50,100 , and $150 \mu \mathrm{g} / \mathrm{mL}$ anatase and rutile $\mathrm{TiO}_{2}$ nanoparticles for 2 days, the obvious decrease of cell viability was observed. And further studies showed that $\mathrm{TiO}_{2}$ nanoparticles exposure could induce the high expression of proinflammatory cytokines TNF- $\alpha$ and IL-6, especially in $150 \mu \mathrm{g} / \mathrm{mL}$ group. The long-rod rutile $\mathrm{TiO}_{2}$ had more strong effects on cell viability and proinflammatory cytokines induction than red-blood cells like anatase $\mathrm{TiO}_{2}$. Results indicated that $\mathrm{TiO}_{2}$ nanoparticles exposure could impair the function of primary cultured cardiac myocytes of rat. Therefore, these findings support the view that much more attention should be aroused on the application of these nanoparticles and their potential exposure effects on human beings.
\end{abstract}

\section{Introduction}

Nanoparticles have a large surface-to-volume ratio, high chemical reactivity, high internal pore volumes, and enhanced cell penetrability [1-3]. Because of these special properties, nanomaterials are applicable to the fields of medicine, food industry, environment, energy, biotechnology, and so on [4-7]. Despite the extensive use of nanomaterials, current studies indicate that certain nanoparticles may induce multiple unpredictable effects on human health [8-11].

Titanium dioxide $\left(\mathrm{TiO}_{2}\right)$ nanoparticle, noncombustible and odorless powder, is produced abundantly and used widely in an increasing number of human products including paints, cosmetics, sterilization, food additives, biomedical ceramic, and implanted biomaterials because of its high stability, anticorrosion, and photocatalytic property [12]. The extensive use of $\mathrm{TiO}_{2}$ nanoparticles in the industry and our daily life demand intensified research efforts regarding their potential toxicity and possible health effects $[13,14]$.
In recent years, numerous studies have definitely showed that $\mathrm{TiO}_{2}$ nanoparticles exposure has negative effects on the respiratory system or the metabolic circle system of organisms [15]. In vitro studies have demonstrated that both rutile and anatase $\mathrm{TiO}_{2}$ nanoparticles impaired cellular function of human dermal fibroblasts and decreased cellular area, proliferation, mobility, and ability to contact collagen, with the latter being more potent in inducing damage [16]. Animal studies have revealed that the inhaled nanoparticles can readily deposit in lung tissue and induce the increased neutrophils, the progressively fibroproliferative lesions, the epithelial metaplasia, and the inflammatory response in lung alveoli $[17,18]$. Moreover, the intraperitoneally injected and orally ingested $\mathrm{TiO}_{2}$ nanoparticles would cause transcytosis across epithelial and endothelial cells into the blood circulation, respectively, and can be entrapped in the reticuloendothelial system $[15,19]$.

$\mathrm{Wu}$ et al. found that $\mathrm{TiO}_{2}$ nanoparticles could be accumulated in the spleen, liver, and heart after a subchronic 
dermal exposure, but the heart showed only small traces of white blood cells in the anatase $10 \mathrm{~nm}$ group [20]. A recent study showed that $\mathrm{TiO}_{2}$ nanoparticles could enter the heart and increase reactive oxygen species accumulation, which in turn reduce activities of antioxidant enzymes and antioxidant contents, promote oxidation of DNA in the heart, and result in inflammation, cell necrosis, and sparse cardiac muscle fibers [21]. Our previous in vivo studies demonstrated that the intra-articular injected anatase $\mathrm{TiO}_{2}$ nanoparticles had a potential toxicological effect on major organs of rats, including the histopathological changes of the heart [22]. Thus, the effects of $\mathrm{TiO}_{2}$ nanoparticles on cardiovascular system need to be elucidated in great detail. In this study, we tested the effects of two different types of $\mathrm{TiO}_{2}$ nanoparticles on the primary cultured cardiac myocytes of rat and observed increased expression of proinflammatory cytokines and decreased cell viability.

\section{Material and Methods}

2.1. Materials and Characterization. The commercially pure anatase $\mathrm{TiO}_{2}$ nanoparticles (Anatase, Rutile, Wan Jing New Material Co., Ltd., purity $>99.8 \%$ ) without any coating were used in this study. A few of $\mathrm{TiO}_{2}$ nanoparticles were suspended in anhydrous ethanol and ultrasonicated for $5 \mathrm{~s} \times$ 10 circles at $200 \mathrm{~W}$. The suspension was dipped on the clean silicon wafer. The size of $\mathrm{TiO}_{2}$ nanoparticles was detected by scanning electron microscopy (Hitachi S-4800 SEM). Transmission electron microscopy (TEM, FEI Tecnai G2 F20 S-Twin) was used to characterize the microstructure profile of $\mathrm{TiO}_{2}$ nanoparticles. The surface properties for $\mathrm{TiO}_{2}$ nanoparticles such as specific surface area, average pore diameter, and pore volume were determined under Quadrasorb SI analyzer (Quantachrome Instruments, USA) by $\mathrm{N}_{2}$ absorption at $77.3 \mathrm{~K}$.

To determine the dispersion and aggregation status of $\mathrm{TiO}_{2}$ nanoparticles in water, the dynamic light scattering (DLS) method was performed by particle size and zeta potential analyzer (Zetasizer Nano ZS90, Malven Instruments, UK).

2.2. Isolation and Culture of Rat Cardiac Myocytes. Primary cultured cardiac myocytes were prepared from ventricles of neonatal (1-3d old) Sprague-Dawley rats (the Department of Laboratory Animal Sciences of Peking University, Beijing, China) according to a previously described method [23]. When a neonatal rat was decapitated, the chest cavity was opened, and the heart was rapidly excised. The ventricles were gently stirred for a 5-min period in digestion buffer containing $0.1 \%$ trypsin (Amresco) and $0.01 \%$ collagenase II (Sigma) at $37^{\circ} \mathrm{C}$. The collected enzyme solution was centrifuged at $1000 \mathrm{rpm}$ for $5 \mathrm{~min}$, the supernatant discarded, and the pellet cells resuspended in Dulbecco's modified Eagle's medium (DMEM, Gibco) containing 15\% fetal bovine serum (FBS, Gibco). This cycle was repeated about seven to ten times until all tissues were digested. The dissociated cells were preplated into $100 \mathrm{~mm}$ culture dishes in DMEM with 15\% FBS for $1.5 \mathrm{~h}$ at $37^{\circ} \mathrm{C}$ to make cardiac fibroblasts adhered to culture dishes.
Then the nonadherent cardiac myocytes were collected and plated on culture dishes and cultured in DMEM containing $15 \%$ FBS. At the first $24 \mathrm{~h}, 0.1 \mathrm{mmol} / \mathrm{L}$ 5-Bromodeoxyuridine (BrdU, Sigma-Aldrich) was added in the medium to inhibit the growth of cardiac fibroblasts. By incubating for $72 \mathrm{~h}$ on average, the cardiac myocytes were beating spontaneously and synchronously at a stable rate. The medium was removed and replaced by 50,100 , and $150 \mu \mathrm{g} / \mathrm{mL}$ anatase and rutile $\mathrm{TiO}_{2}$ solution, respectively. Cell morphology was assessed using an inverted phase contrast microscope (Olympus IX71).

2.3. Cell Viability Detection. Cell viability was measured using the 3-(4,5-dimethyl-2-thiazolyl)-2,5-diphenyl-[2H]tetrazolium bromide (MTT) assay. The dye MTT is taken up and metabolized to purple by viable mitochondria. Cells were counted and plated in a 96-well plate at a rate of $1 \times 10^{4}$ cells per well and incubated in $200 \mu \mathrm{L}$ cell culture medium. After 3 days, when primary cultured cardiac myocytes were beating spontaneously, the medium was removed and replaced by 50,100 , and $150 \mu \mathrm{g} / \mathrm{mL}$ anatase and rutile $\mathrm{TiO}_{2}$ solution, respectively. Prior to dilution with culture medium, the $\mathrm{TiO}_{2}$ powder was sterilized by autoclaving. After incubation for 2 days, the cell culture medium was discarded and replaced with fresh DMEM and a $20 \mu \mathrm{L}$ MTT solution $(5 \mathrm{mg} / \mathrm{mL}$, prepared with $\mathrm{PBS}, \mathrm{pH} 7.4)$ was added to each well and incubated at $37^{\circ} \mathrm{C}$ in $5 \% \mathrm{CO}_{2}$ for an additional $4 \mathrm{~h}$. The purple MTT was dissolved in $150 \mu \mathrm{L}$ dimethyl sulfoxide solution (DMSO, Sigma-Aldrich). The activity of the mitochondria, reflecting cellular viability, was evaluated by measuring the optical density at $490 \mathrm{~nm}$ using an ELISA microplate reader (Thermo). The cell viability (\%) of the treated cells was calculated in relation to the control cells (100\%).

2.4. RT-PCR. Total RNA was isolated from differentially treated rat cardiac myocytes using TRIzol reagent (Invitrogen Life Technologies) following the manufacturer's instructions. Total RNA ( $2 \mu \mathrm{g})$ was reversely transcribed using M-MLV Reverse Transcriptase (New England BioLabs) and oligo$\mathrm{d}(\mathrm{T})_{18}$ primers (Takara). cDNA $(1 \mu \mathrm{L})$ was amplified by semiquantitative PCR using Premix Taq (Takara). GAPDH was used as internal control to normalize the amplification result. The primer sequences used for RT-PCR are shown in Table 1.

2.5. Statistical Analysis. All data were expressed as means \pm standard deviation (SD). A one-way analysis of variance (ANOVA) and LSD test were performed with SPSS software (Version 11.5). Difference was considered to be statistically significant and different when $P<0.05$.

\section{Results and Discussion}

3.1. $\mathrm{TiO}_{2}$ Nanoparticles Characterization. The SEM micrographs of $\mathrm{TiO}_{2}$ nanoparticles were shown in Figure 1. The anatase $\mathrm{TiO}_{2}$ was red-blood cells like with the average diameter of $45.87 \pm 7.75 \mathrm{~nm}$. From the TEM images (Figure 2), we observed that the anatase $\mathrm{TiO}_{2}$ showed sheet or nearly belt shapes with the width of $13.42 \pm 3.94 \mathrm{~nm}$ and the length 
TABLE 1: Gene specific primers for RT-PCR.

\begin{tabular}{lcccc}
\hline Gene & Orientation accession & Primer sequence & Length (bp) & Product length (bp) \\
\hline \multirow{2}{*}{ GAPDH } & Forward & $5^{\prime}$-GGCACAGTCAAGGCTGAGAATG-3' & 22 & 143 \\
& Reverse & $5^{\prime}$-ATGGTGGTGAAGACGCCAGTA-3' & 21 & 20 \\
TNF- $\alpha$ & Forward & $5^{\prime}$-CAGCAGATGGGCTGTACCTT-3 & 301 \\
& Reverse & $5^{\prime}$-AAGTAGACCTGCCCGGACTC-3' & 20 & 25 \\
IL-6 & Forward & $5^{\prime}$-GACTGATGTTGTTGACAGCCACTGC-3' & 25 & 508 \\
\hline
\end{tabular}

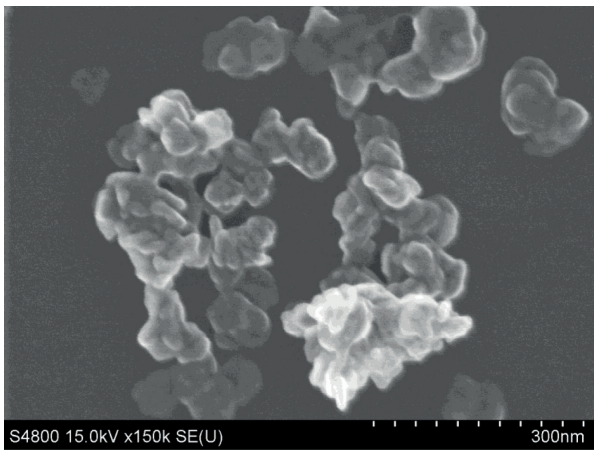

(a)

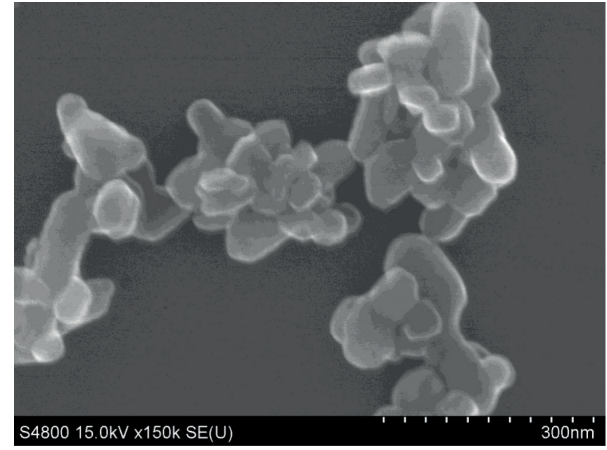

(b)

FIGURE 1: Micrograph of anatase (a) and rutile (b) nano- $\mathrm{TiO}_{2}$ by scanning electron microscopy.

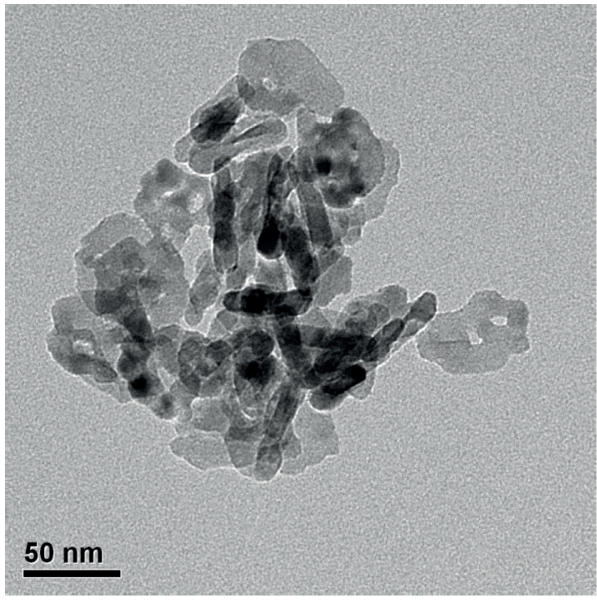

(a)

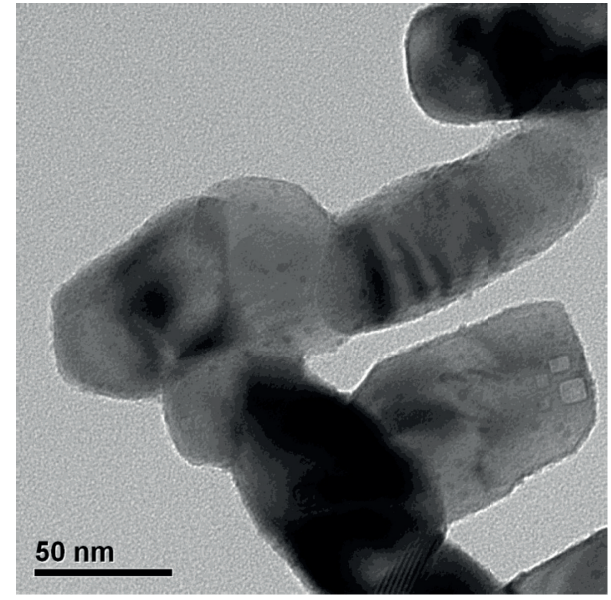

(b)

FIgURE 2: Micrograph of anatase (a) and rutile (b) nano- $\mathrm{TiO}_{2}$ by transmission electron microscopy.

of $45.35 \pm 8.70 \mathrm{~nm}$, which was consistent with the SEM results. Using the BET method, the specific surface area was determined as $97.75 \mathrm{~m}^{2} / \mathrm{g}$. The average pore diameter was $1.79 \mathrm{~nm}$, and the total pore volume was $0.56 \mathrm{cc} / \mathrm{g}$. For the rutile $\mathrm{TiO}_{2}$, it was long rod with the average length of $86.55 \pm$ $12.13 \mathrm{~nm}$ and the average diameter of $52.37 \pm 7.35 \mathrm{~nm}$. The specific surface area for rutile $\mathrm{TiO}_{2}$ was $21.51 \mathrm{~m}^{2} / \mathrm{g}$, which was lower than the anatase. The average pore diameter was $2.17 \mathrm{~nm}$ and the total pore volume was $0.22 \mathrm{cc} / \mathrm{g}$. The physical properties of $\mathrm{TiO}_{2}$ nanoparticles were well characterized and listed in Table 2.

Furthermore, the dynamic light scattering method was used to analyze the aggregation ability of $\mathrm{TiO}_{2}$ nanoparticles in solution. The size distributions for two different particles were shown in Figure 3. The average diameter of anatase $\mathrm{TiO}_{2}$ at the peak was $166.6 \mathrm{~nm}$. For the rutile $\mathrm{TiO}_{2}$, it was $408.7 \mathrm{~nm}$ at the peak, which suggested that $\mathrm{TiO}_{2}$ nanoparticles were agglomerated and aggregated easily in solution. The zeta potential of $\mathrm{TiO}_{2}$ nanoparticles in aqueous solution was 5.72 and $2.28 \mathrm{mV}$ for anatase and rutile, respectively (Table 2).

3.2. Cell Coculture with $\mathrm{TiO}_{2}$ Nanoparticles. In order to determine the effects of $\mathrm{TiO}_{2}$ nanoparticles exposure on cell morphology, we incubated primary cultured cardiac myocytes of rat with the anatase and rutile $\mathrm{TiO}_{2}$ nanoparticles, respectively. The change of cell morphology was shown 
TABLE 2: Characterization of nano- $\mathrm{TiO}_{2}$.

\begin{tabular}{|c|c|c|c|c|c|c|c|}
\hline Crystal & Morphology & Size $(\mathrm{nm})$ & $\begin{array}{l}\text { Specific surface } \\
\text { area }\left(\mathrm{m}^{2} / \mathrm{g}\right)\end{array}$ & $\begin{array}{l}\text { Average pore } \\
\text { diameter (nm) }\end{array}$ & $\begin{array}{c}\text { Total pore } \\
\text { volume }(\mathrm{cc} / \mathrm{g})\end{array}$ & $Z$-Ave (d.nm) & $\begin{array}{l}\text { Zeta potential } \\
(\mathrm{mV})\end{array}$ \\
\hline Anatase & Red-blood cells like & $D: 45.87 \pm 7.75$ & 97.75 & 1.79 & 0.56 & 166.6 & 5.72 \\
\hline Rutile & Long rod & $\begin{array}{l}L: 86.55 \pm 12.13 \\
D: 52.37 \pm 7.35\end{array}$ & 21.51 & 2.17 & 0.22 & 408.7 & 2.28 \\
\hline
\end{tabular}

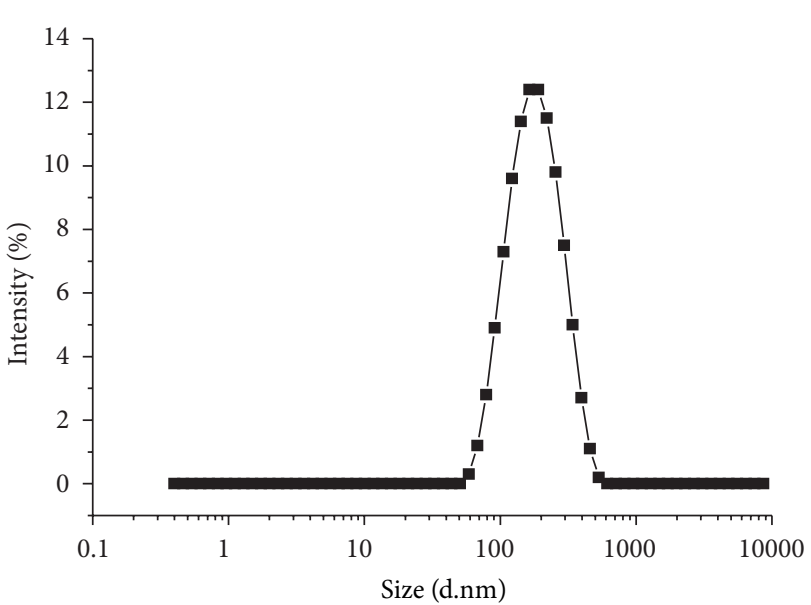

(a)

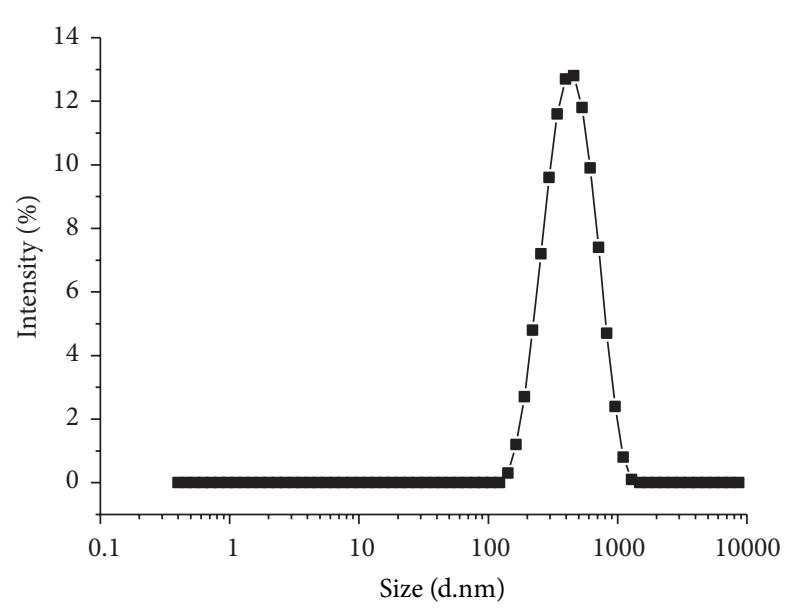

(b)

FIgURE 3: Diameter distribution of anatase (a) and rutile (b) $\mathrm{TiO}_{2}$ particles in aqueous solution.

in Figure 4. Morphologies of control cells showed that rat cardiac myocytes were fusiform, fibriform, and polygon under inverted microscope, and they were well spread on the surface of cell plate (Figure 4(a)). However, the cells exposed to 50,100 , and $150 \mu \mathrm{g} / \mathrm{mL}$ anatase or rutile $\mathrm{TiO}_{2}$ nanoparticles for 2 days had become elongated and appeared to detach from the surface of cell plate (Figures $4(\mathrm{~b})-4(\mathrm{~g})$ ). After 2 days, we observed that a large amount of $\mathrm{TiO}_{2}$ nanoparticles were phagocytosed into the cytoplasma, and fewer cells was survived compared with the control group (Figure 4). In previous studies, $\mathrm{TiO}_{2}$ nanoparticles were shown to be capsulated in single vesicles of human dermal fibroblasts and nasal mucosa cells $[16,24]$, which also indicated the engulfment of $\mathrm{TiO}_{2}$ nanoparticles by viable cells.

Recently, it has been shown that size and shape can have different adverse effects on cell function [25-28]. The small size of nanoparticles may cause high toxicity because of their large surface area, enhanced chemical reactivity, and easier cell penetration [29-31]. Rod- or needle-shaped nanoparticles are more easily taken up by cells. Gratton et al. declared that particles with aspect ratio of 3 were internalized by Hela cells about 4 times the spheres of the same volume [32]. Considering the previous reports, in this study, we selected red-blood cells like anatase $\mathrm{TiO}_{2}$ with the diameter of $45.87 \pm 7.75 \mathrm{~nm}$ and long-rod rutile $\mathrm{TiO}_{2}$ with the average length of $86.55 \pm 12.13 \mathrm{~nm}$ and the average diameter of $52.37 \pm 7.35 \mathrm{~nm}$. It is to be expected that the nonspherical particles can also exacerbate the adverse effects. Our results suggested that although the cardiac myocytes can attach and spread by coculturing with the anatase and rutile particles, the morphology of the cells was affected as exemplified by the elongated cells spread.
3.3. Effects of $\mathrm{TiO}_{2}$ Nanoparticles on Cell Viability. The cellular behavior on biomaterials is an important factor for evaluation of the biocompatibility of biomaterials [33]. Cell growth with materials is the first sequential reaction when in contact with material surface, which is crucial for cell survival [34, 35]. Previous studies reported that cells cultured with $\mathrm{TiO}_{2}$ nanoparticles showed a dramatic decrease in growth rate with exposure to concentrations larger than $0.1 \mathrm{mg} / \mathrm{mL}[16,36]$. In this study, the 50,100 , and $150 \mu \mathrm{g} / \mathrm{mL}$ anatase or rutile $\mathrm{TiO}_{2}$ nanoparticles were selected to stimulate the rat cardiac myocytes from primary cultures, aiming to investigate the effect of $\mathrm{TiO}_{2}$ nanoparticles on the relative cell viability of cardiac myocytes.

To evaluate relative cell viability of rat cardiac myocytes cocultured with different $\mathrm{TiO}_{2}$ nanoparticles (anatase and rutile) at different concentrations, the MTT assay was used in the present study. Figure 5 showed the relative cell viability after being exposed to the anatase and rutile $\mathrm{TiO}_{2}$ nanoparticles for 2 days, respectively. The absorbance at $490 \mathrm{~nm}$ was detected, and the relative cell viability in the exposed group (\%) was expressed as a percentage relative to the untreated control group. The viability of primary cardiac myocytes was significantly decreased after exposure to 50, 100 , and $150 \mu \mathrm{g} / \mathrm{mL} \mathrm{TiO}_{2}$ nanoparticles. Comparing Figures 5(a) with 5(b), we observed that the long-rod rutile particles, with even lower concentrations, can produce more damage than the red-blood cells like anatase particles. Our results were consistent with the previous results. Huang et al. also reported that the silica particles with large aspect ratios were taken up in larger amounts and had a greater impact on cellular proliferation [37]. In this study, because of the shape 


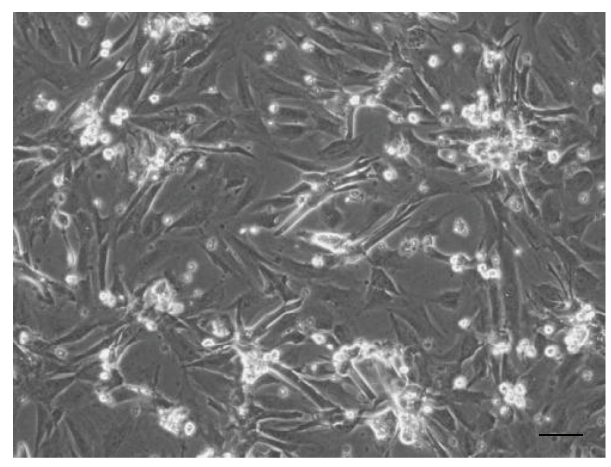

(a)

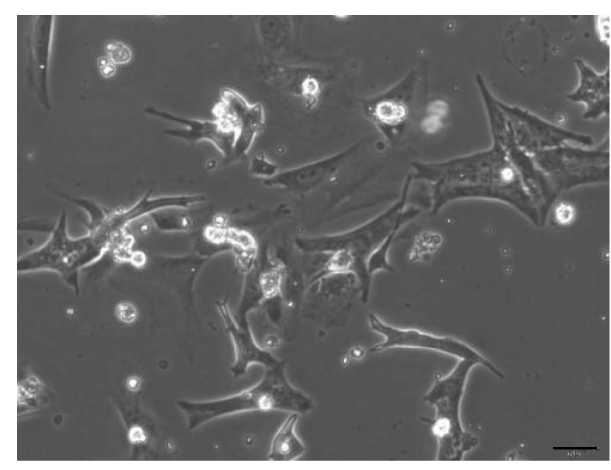

(b)

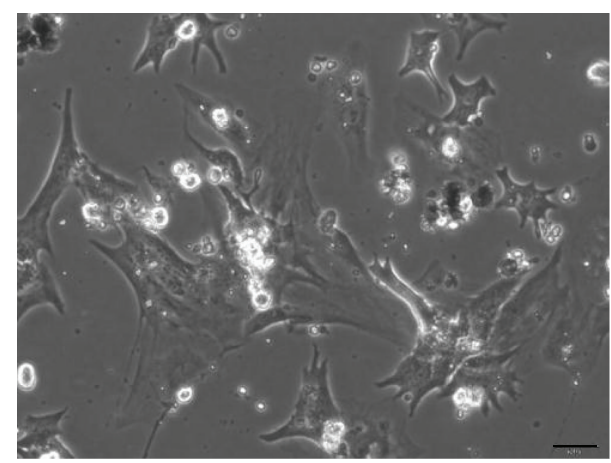

(c)

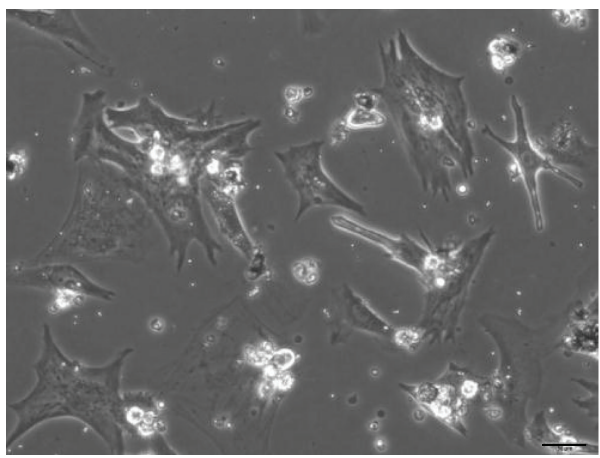

(d)

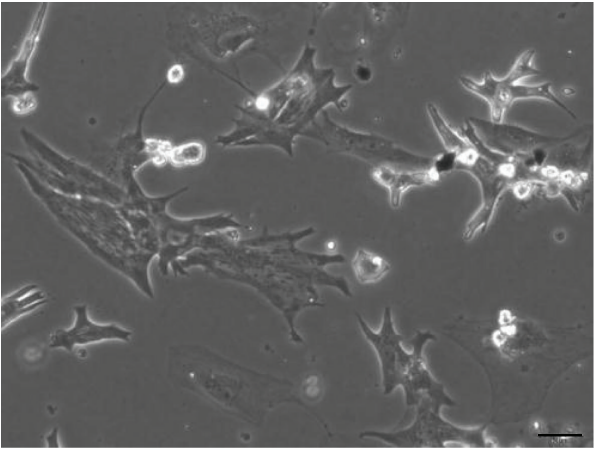

(e)

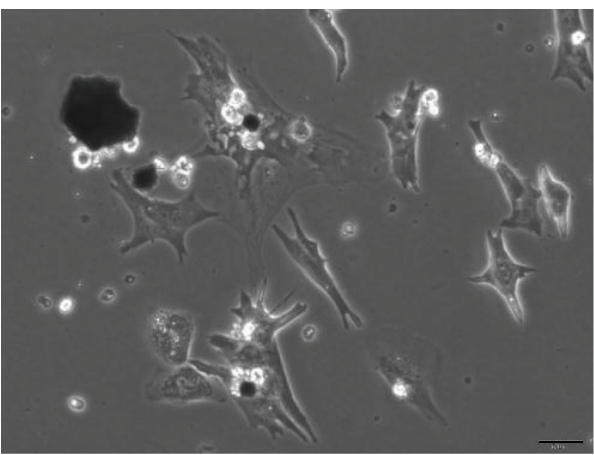

(f)

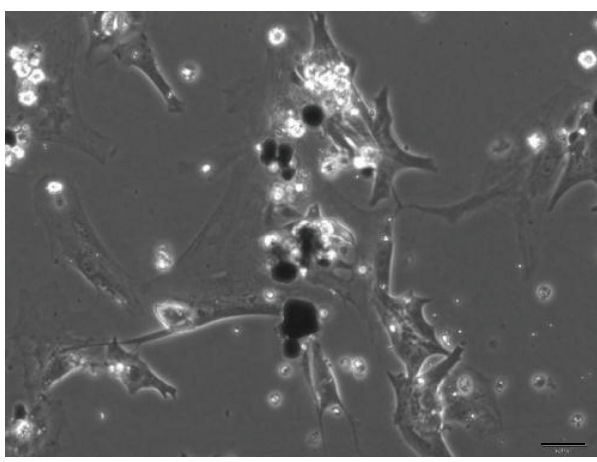

(g)

FIGURE 4: Morphological change of primary cardiac myocytes induced by $\mathrm{TiO}_{2}$ particles. The primary cultured cardiac myocytes of rat exposed to 50 (b), 100 (c), and 150 (d) $\mu \mathrm{g} / \mathrm{mL}$ anatase $\mathrm{TiO}_{2}$ nanoparticles or 50 (e), 100 (f), and 150 (g) $\mu \mathrm{g} / \mathrm{mL}$ rutile $\mathrm{TiO}{ }_{2}$ nanoparticles for 2 days. (a) represents the control cells. Scale bar is $50 \mu \mathrm{m}$. 


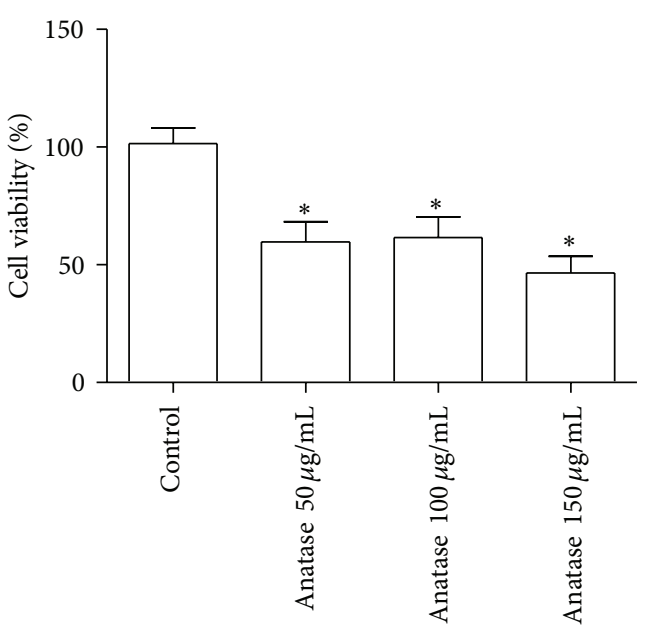

(a)

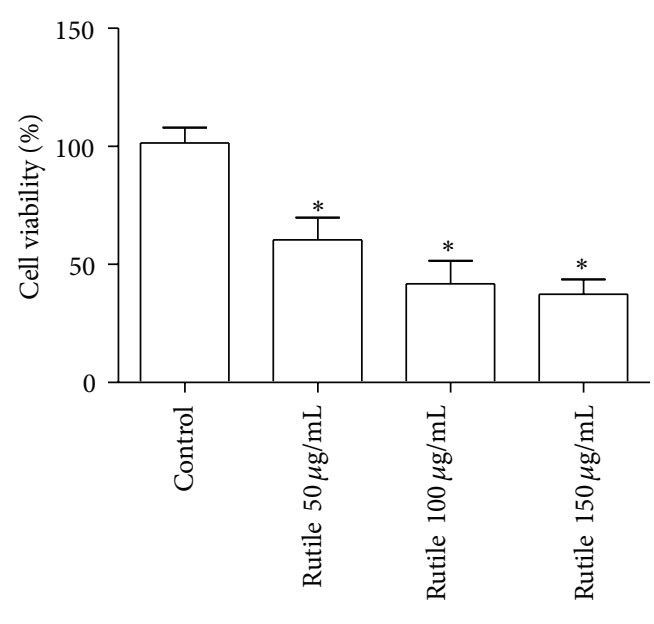

(b)

Figure 5: Cell viability after exposure to $\mathrm{TiO}_{2}$ particles. The relative cell viability after being exposed to 50,100 , and $150 \mu \mathrm{g} / \mathrm{mL}$ anatase (a) or rutile (b) $\mathrm{TiO}_{2}$ nanoparticles for 2 days was detected by MTT assay. ${ }^{*} \mathrm{P}<0.05$ compared to the control.

difference, the anatase particles with red-blood cells like may be more suitable and biocompatible with cells than long-rod rutile particles.

3.4. Effects of $\mathrm{TiO}_{2}$ Nanoparticles on Expression of Proinflammatory Cytokines. Many reports claimed that the cytotoxicity of $\mathrm{TiO}_{2}$ nanoparticles was related to the induced oxidative damage [38]. When antioxidant defenses fail to restore redox equilibrium, escalation in the level of oxidative stress could lead to cellular injury [39]. One mechanism is the activation of proinflammatory cascades [40]. In order to study whether $\mathrm{TiO}_{2}$ nanoparticles induced proinflammation response of primary cultured cardiac myocytes, the cells were exposed to 50,100 , and $150 \mu \mathrm{g} / \mathrm{mL}$ anatase or rutile $\mathrm{TiO}_{2}$ nanoparticles for 2 days. The expression of proinflammatory cytokines TNF- $\alpha$ and IL- 6 with control cells was determined through RT-PCR analysis.

We found that there was no obvious change in the expression of TNF- $\alpha$ and IL- 6 following 2-day treatment with $50 \mu \mathrm{g} / \mathrm{mL}$ anatase particles (Figures $6(\mathrm{a})$ and $6(\mathrm{c})$ ). But the expression of TNF- $\alpha$ and IL- 6 mRNA increased following treatment with 100 and $150 \mu \mathrm{g} / \mathrm{mL}$ anatase particles (Figures 6(a) and 6(c)). The long-rod rutile particles showed more strong effects on the expression of proinflammatory cytokines TNF- $\alpha$ and IL-6 (Figures 6(b) and 6(d)). The proinflammatory cytokines TNF- $\alpha$, and IL- 6 secreted by the activated macrophages, fibrolasts and neutrophils are the molecular messengers, which have been hypothesized to influence the tissue or cell response to biomaterials [41]. This analysis suggested that the cytotoxicity of $\mathrm{TiO}_{2}$ nanoparticles might correlate with the induction of proinflammatory cytokines and the long-rod rutile $\mathrm{TiO}_{2}$ particles could produce more damage to the cells than red-blood cells like anatase.

\section{Conclusion}

In this study, the red-blood cells like anatase and the longrod rutile $\mathrm{TiO}_{2}$ nanoparticles were well characterized using different methods. Then we detected that both anatase and rutile $\mathrm{TiO}_{2}$ nanoparticles impaired the function of the primary cultured cardiac myocytes of rat. After exposure to these nanoparticles, the primary cells had become elongated and appeared to detach from the surface of cell plate. After exposure to 50,100 , and $150 \mu \mathrm{g} / \mathrm{mL}$ anatase or rutile $\mathrm{TiO}_{2}$ nanoparticles for 2 days, the viability of cardiac myocytes decreased significantly. RT-PCR results showed anatase or rutile exposure could induce the expression of proinflammatory cytokines TNF- $\alpha$ and IL-6. Furthermore, the longrod rutile $\mathrm{TiO}_{2}$ had more strong effects on cell viability and proinflammatory cytokines expression than red-blood cells like anatase $\mathrm{TiO}_{2}$. Considering the broad applications of these $\mathrm{TiO}_{2}$ nanoparticles, much more attention should be aroused on their potential exposure effects on human beings.

\section{Conflict of Interests}

The authors declare that they have no financial or personal relationship with any person or organization that may inappropriately influence they work. There is no professional or commercial interest of any kind in all the commercial identities mentioned in their paper.

\section{Authors' Contribution}

Wei Song and Jiangxue Wang equally contributed to this work.

\section{Acknowledgments}

This study was supported by funds from National Basic Research Program of China (973 Program, 2011CB710901), the National Natural Science Foundation of China (NSFC) Research Grants (31271008, 31300769, 31100666, 10925208, and 11120101001), the 111 Project (B13003), International Joint Research Center of Aerospace Biotechnology and Medical 


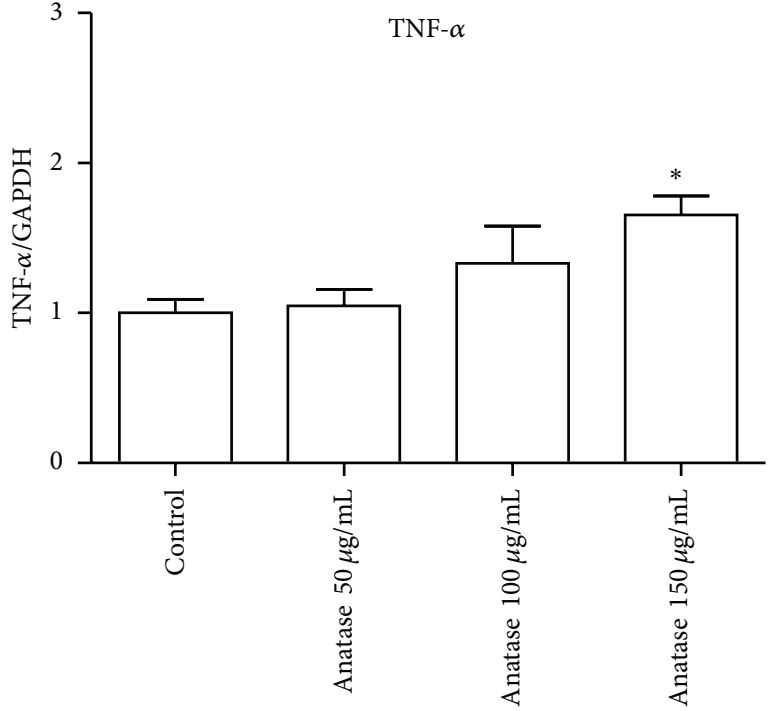

(a)

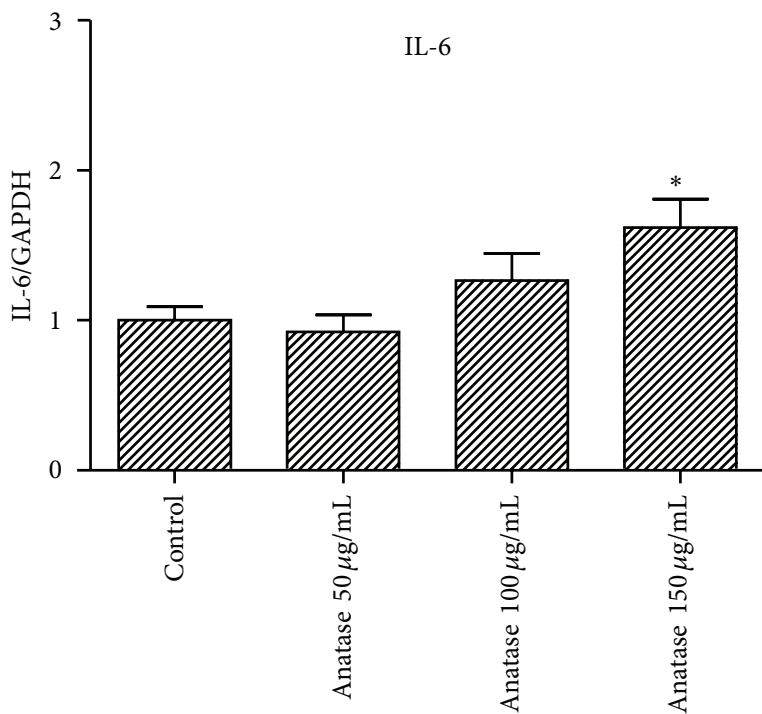

(c)

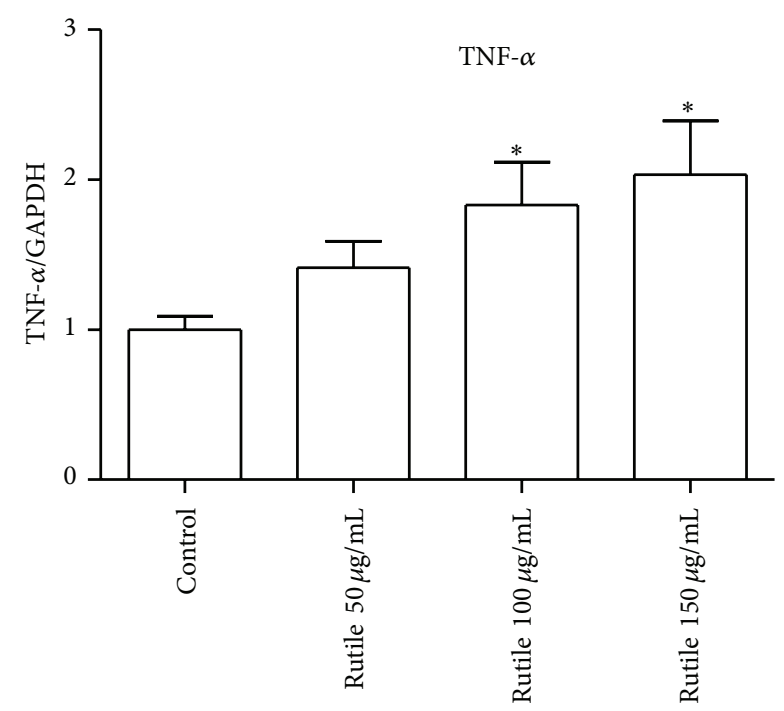

(b)

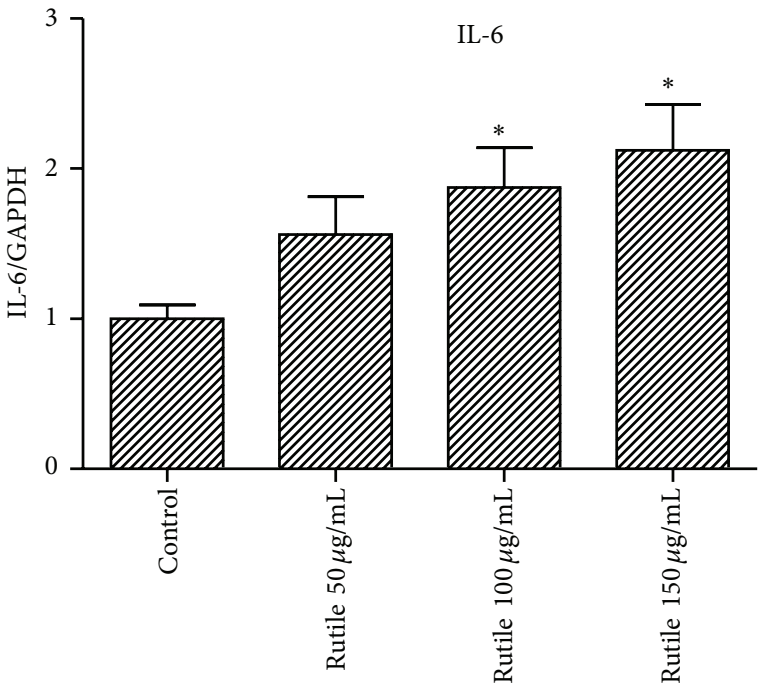

(d)

FIGURE 6: Expression of TNF- $\alpha$ and IL-6 mRNA in primary cardiac myocytes. The cardiac myocytes were co-cultured with 50, 100, and $150 \mu \mathrm{g} / \mathrm{mL}$ anatase or rutile $\mathrm{TiO}_{2}$ nanoparticles for 2 days, and the expression of proinflammatory cytokines TNF- $\alpha$ (a, b) and IL-6 (c, d) was detected by RT-PCR. Each error bar represents a standard deviation calculated from experiments performed in triplicate. ${ }^{*} P<0.05$ compared to the control.

Engineering, Ministry of Science and Technology of China, and National High Technology Research and Development Program of China (863 program, 2011AA02A102).

\section{References}

[1] S. Linse, C. Cabaleiro-Lago, W. F. Xue et al., "Nucleation of protein fibrillation by nanoparticles," Proceedings of the National Academy of Sciences of the United States of America, vol. 104, no. 21, pp. 8691-8696, 2007.

[2] X. Li, H. Gao, M. Uo et al., "Effect of carbon nanotubes on cellular functions in vitro," Journal of Biomedical Materials Research Part A, vol. 91, no. 1, pp. 132-139, 2009.
[3] X. Li, L. Wang, Y. Fan, Q. Feng, and F. Cui, "Biocompatibility and toxicity of nanoparticles and nanotubes," Journal of Nanomaterials, vol. 2012, Article ID 548389, 19 pages, 2012.

[4] L. Yildirimer, N. T. K. Thanh, M. Loizidou, and A. M. Seifalian, "Toxicological considerations of clinically applicable nanoparticles," Nano Today, vol. 6, no. 6, pp. 585-607, 2011.

[5] X. Li, L. Wang, Y. Fan, Q. Feng, F. Z. Cui, and F. Watari, "Nanostructured scaffolds for bone tissue engineering," Journal of Biomedical Materials Research Part A, vol. 101, no. 8, pp. 24242435, 2013.

[6] X. Li, H. Gao, M. Uo et al., "Maturation of osteoblast-like SaoS2 induced by carbon nanotubes," Biomedical Materials, vol. 4, no. 1, Article ID 015005, 2009. 
[7] X. Li, Q. Feng, X. Liu, W. Dong, and F. Cui, “Collagen-based implants reinforced by chitin fibres in a goat shank bone defect model," Biomaterials, vol. 27, no. 9, pp. 1917-1923, 2006.

[8] K. Donaldson, V. Stone, C. L. Tran, W. Kreyling, and P. J. A. Borm, "Nanotoxicology," Occupational and Environmental Medicine, vol. 61, no. 9, pp. 727-728, 2004.

[9] A. Nel, T. Xia, L. Mädler, and N. Li, "Toxic potential of materials at the nanolevel," Science, vol. 311, no. 5761, pp. 622-627, 2006.

[10] X. Li, H. Liu, X. Niu et al., "The use of carbon nanotubes to induce osteogenic differentiation of human adipose-derived MSCs in vitro and ectopic bone formation in vivo," Biomaterials, vol. 33, no. 19, pp. 4818-4827, 2012.

[11] X. Li, H. Liu, X. Niu et al., "Osteogenic differentiation of human adipose-derived stem cells induced by osteoinductive calcium phosphate ceramics," Journal of Biomedical Materials Research Part B, vol. 97, no. 1, pp. 10-19, 2011.

[12] D. B. Warheit, R. A. Hoke, C. Finlay, E. M. Donner, K. L. Reed, and C. M. Sayes, "Development of a base set of toxicity tests using ultrafine $\mathrm{TiO}_{2}$ particles as a component of nanoparticle risk management," Toxicology Letters, vol. 171, no. 3, pp. 99-110, 2007.

[13] M. Skocaj, M. Filipic, J. Petkovic, and S. Novak, "Titanium dioxide in our everyday life; Is it safe?" Radiology and Oncology, vol. 45, no. 4, pp. 227-247, 2011.

[14] G. Oberdörster, E. Oberdörster, and J. Oberdörster, "Nanotoxicology: an emerging discipline evolving from studies of ultrafine particles," Environmental Health Perspectives, vol. 113, no. 7, pp. 823-839, 2005.

[15] J. Wang, G. Zhou, C. Chen et al., "Acute toxicity and biodistribution of different sized titanium dioxide particles in mice after oral administration," Toxicology Letters, vol. 168, no. 2, pp. 176185, 2007.

[16] Z. Pan, W. Lee, L. Slutsky, R. A. F. Clark, N. Pernodet, and M. H. Rafailovich, "Adverse effects of titanium dioxide nanoparticles on human dermal fibroblasts and how to protect cells," Small, vol. 5, no. 4, pp. 511-520, 2009.

[17] K. J. Barnham, C. L. Masters, and A. I. Bush, "Neurodegenerative diseases and oxidatives stress," Nature Reviews Drug Discovery, vol. 3, no. 3, pp. 205-214, 2004.

[18] D. B. Warheit, W. J. Brock, K. P. Lee, T. R. Webb, and K. L. Reed, "Comparative pulmonary toxicity inhalation and instillation studies with different $\mathrm{TiO}_{2}$ particle formulations: impact of surface treatments on particle toxicity," Toxicological Sciences, vol. 88, no. 2, pp. 514-524, 2005.

[19] D. Olmedo, M. B. Guglielmotti, and R. L. Cabrini, "An experimental study of the dissemination of titanium and zirconium in the body," Journal of Materials Science: Materials in Medicine, vol. 13, no. 8, pp. 793-796, 2002.

[20] J. Wu, W. Liu, C. Xue et al., "Toxicity and penetration of $\mathrm{TiO}_{2}$ nanoparticles in hairless mice and porcine skin after subchronic dermal exposure," Toxicology Letters, vol. 191, no. 1, pp. 1-8, 2009.

[21] L. Sheng, X. Wang, X. Sang et al., "Cardiac oxidative damage in mice following exposure to nanoparticulate titanium dioxide," Journal of Biomedical Materials Research Part A, 2013.

[22] J.-X. Wang, Y.-B. Fan, Y. Gao, Q.-H. Hu, and T.-C. Wang, " $\mathrm{TiO}_{2}$ nanoparticles translocation and potential toxicological effect in rats after intraarticular injection," Biomaterials, vol. 30, no. 27, pp. 4590-4600, 2009.

[23] W. Zheng, Y. B. Lu, S. T. Liang et al., "SIRT1 mediates the protective function of Nkx2.5 during stress in cardiomyocytes," Basic Research in Cardiology, vol. 108, no. 4, p. 364, 2013.
[24] S. Hackenberg, G. Friehs, K. Froelich et al., "Intracellular distribution, geno- and cytotoxic effects of nanosized titanium dioxide particles in the anatase crystal phase on human nasal mucosa cells," Toxicology Letters, vol. 195, no. 1, pp. 9-14, 2010.

[25] Y. Pan, S. Neuss, A. Leifert et al., "Size-dependent cytotoxicity of gold nanoparticles," Small, vol. 3, no. 11, pp. 1941-1949, 2007.

[26] A. E. Nel, L. Mädler, D. Velegol et al., "Understanding biophysicochemical interactions at the nano-bio interface," Nature Materials, vol. 8, no. 7, pp. 543-557, 2009.

[27] X. Li, Y. Yang, Y. Fan, Q. Feng, F. Z. Cui, and F. Watari, "Biocomposites reinforced by fibers or tubes, as scaffolds for tissue engineering or regenerative medicine," Journal of Biomedical Materials Research Part A, 2013.

[28] X. Li, X. Liu, W. Dong et al., "In vitro evaluation of porous poly(L-lactic acid) scaffold reinforced by chitin fibers," Journal of Biomedical Materials Research Part B, vol. 90, no. 2, pp. 503509, 2009.

[29] E. Oberdörster, "Manufactured nanomaterials (fullerenes, C60) induce oxidative stress in the brain of juvenile largemouth bass," Environmental Health Perspectives, vol. 112, no. 10, pp. 10581062,2004

[30] X. Li, Y. Fan, and F. Watari, "Current investigations into carbon nanotubes for biomedical application," Biomedical Materials, vol. 5, no. 2, Article ID 022001, 2010.

[31] X. Li, X. Liu, J. Huang, Y. Fan, and F.-Z. Cui, "Biomedical investigation of CNT based coatings," Surface and Coatings Technology, vol. 206, no. 4, pp. 759-766, 2011.

[32] S. E. Gratton, P. A. Ropp, P. D. Pohlhaus et al., "The effect of particle design on cellular internalization pathways," Proceedings of the National Academy of Sciences of the United States of America, vol. 105, no. 33, pp. 11613-11618, 2008.

[33] X. Li, C. A. van Blitterswijk, Q. Feng, F. Cui, and F. Watari, "The effect of calcium phosphate microstructure on bone-related cells in vitro," Biomaterials, vol. 29, no. 23, pp. 3306-3316, 2008.

[34] W. Shen, K. Cai, Z. Yang, Y. Yan, W. Yang, and P. Liu, "Improved endothelialization of NiTi alloy by VEGF functionalized nanocoating," Colloids and Surfaces B, vol. 94, pp. 347$353,2012$.

[35] X. Li, Y. Huang, L. Zheng et al., "Effect of substrate stiffness on the functions of rat bone marrow and adipose tissue derived mesenchymal stem cells in vitro," Journal of Biomedical Materials Research Part A, 2013.

[36] C. M. Sayes, R. Wahi, P. A. Kurian et al., "Correlating nanoscale titania structure with toxicity: a cytotoxicity and inflammatory response study with human dermal fibroblasts and human lung epithelial cells," Toxicological Sciences, vol. 92, no. 1, pp. 174-185, 2006.

[37] X. Huang, X. Teng, D. Chen, F. Tang, and J. He, “The effect of the shape of mesoporous silica nanoparticles on cellular uptake and cell function," Biomaterials, vol. 31, no. 3, pp. 438-448, 2010.

[38] J.-R. Gurr, A. S. S. Wang, C.-H. Chen, and K.-Y. Jan, "Ultrafine titanium dioxide particles in the absence of photoactivation can induce oxidative damage to human bronchial epithelial cells," Toxicology, vol. 213, no. 1-2, pp. 66-73, 2005.

[39] T. Xia, M. Kovochich, J. Brant et al., "Comparison of the abilities of ambient and manufactured nanoparticles to induce cellular toxicity according to an oxidative stress paradigm," Nano Letters, vol. 6, no. 8, pp. 1794-1807, 2006.

[40] K. Peters, R. E. Unger, C. J. Kirkpatrick, A. M. Gatti, and E. Monari, "Effects of nano-scaled particles on endothelial cell 
function in vitro: studies on viability, proliferation and inflammation," Journal of Materials Science: Materials in Medicine, vol. 15, no. 4, pp. 321-325, 2004.

[41] R. J. Schutte, L. Xie, B. Klitzman, and W. M. Reichert, "In vivo cytokine-associated responses to biomaterials," Biomaterials, vol. 30, no. 2, pp. 160-168, 2009. 

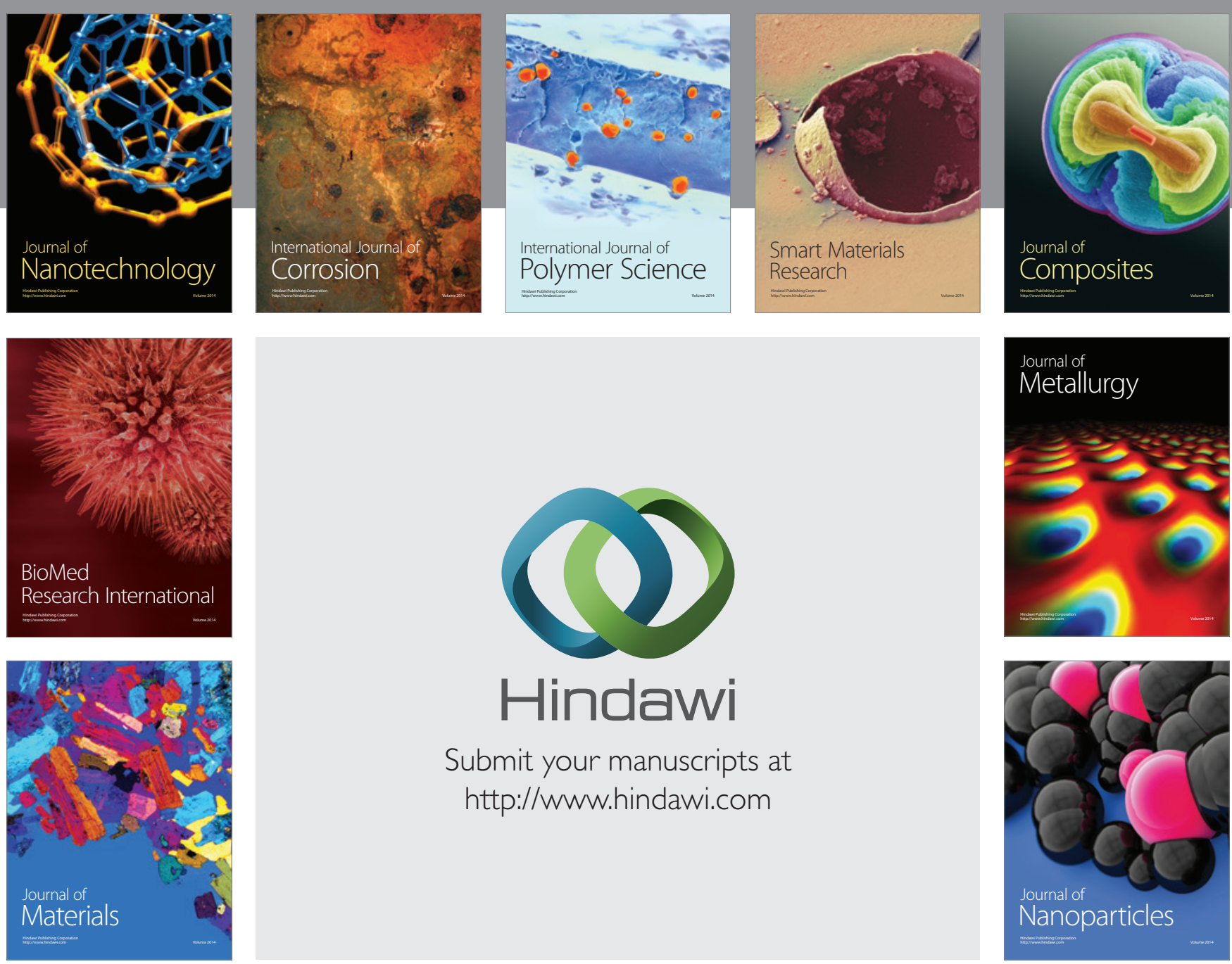

Submit your manuscripts at http://www.hindawi.com
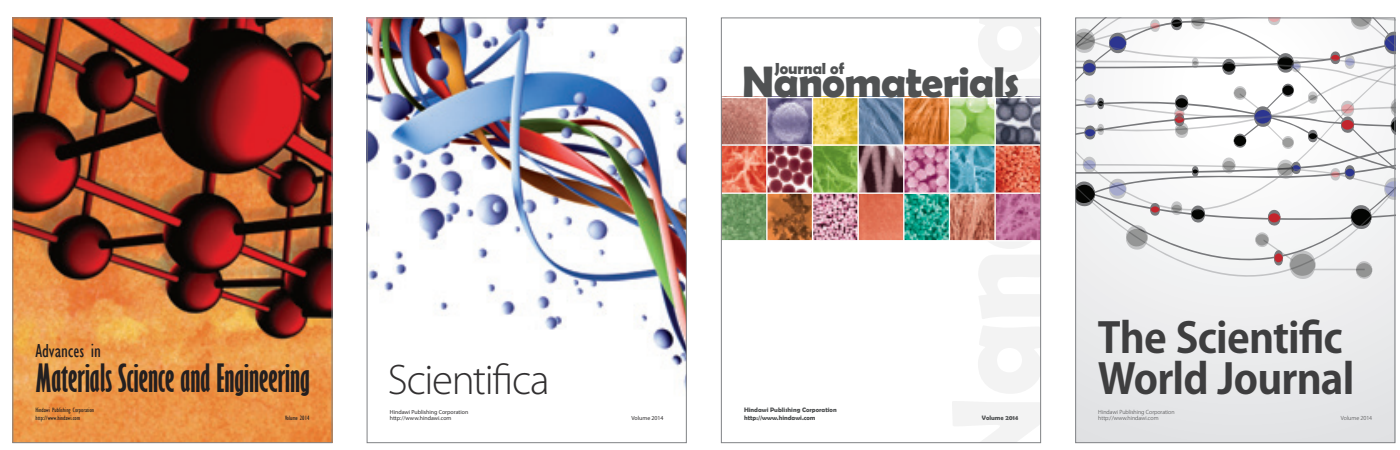

\section{The Scientific World Journal}
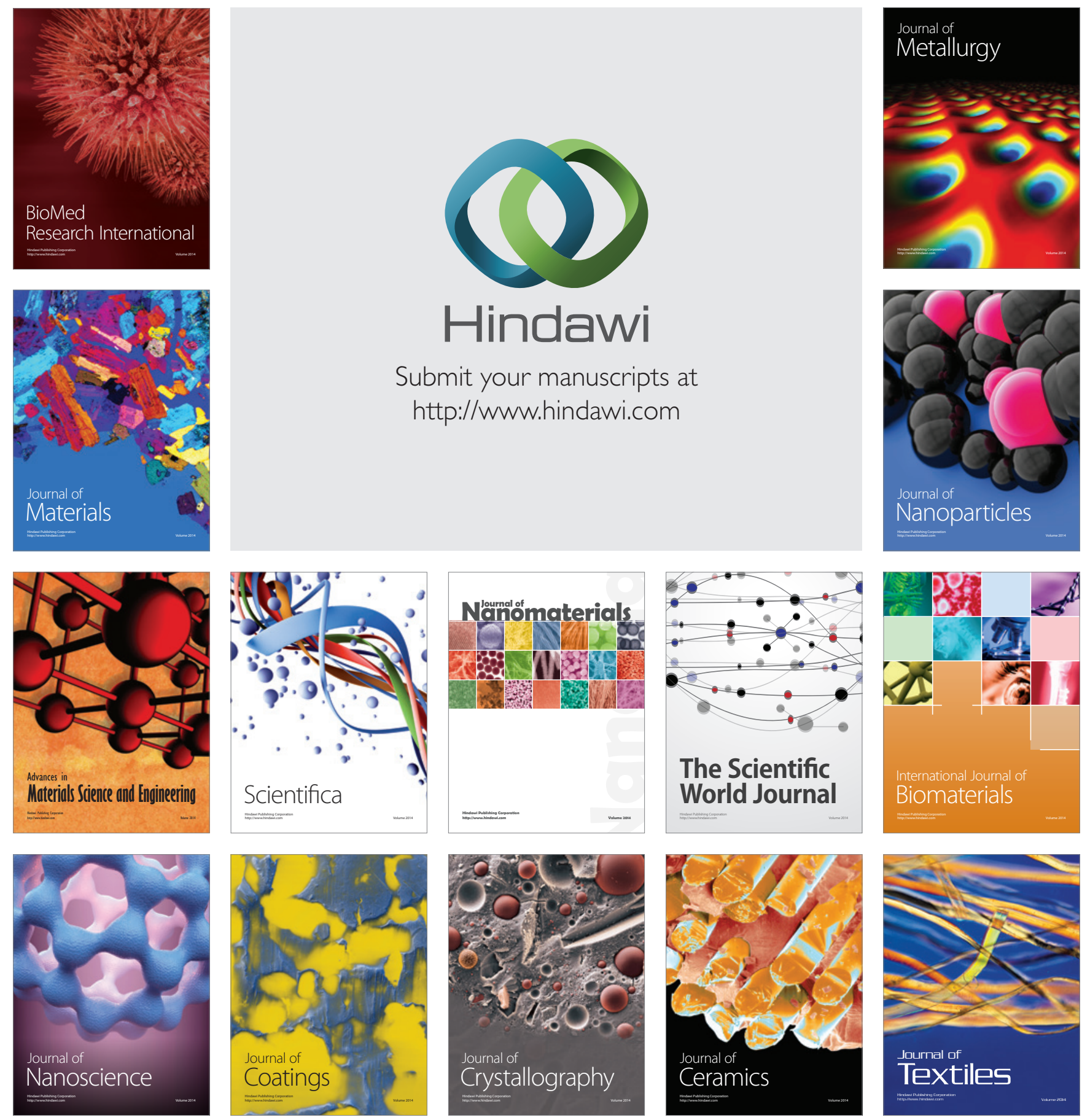